\title{
Comprehensible Input and Krashen's theory
}

by Robert Patrick

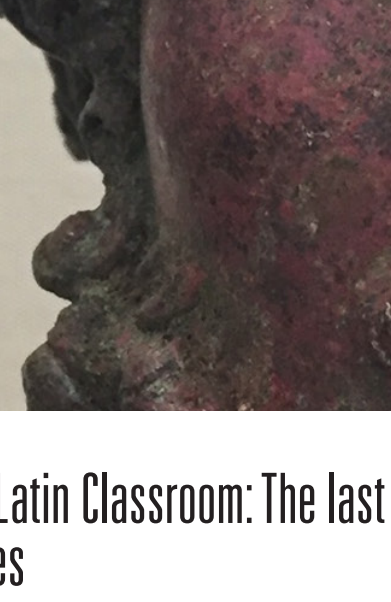

20 years ago, as a relatively new teacher of Latin I had a series of experiences that I can now identify as the beginning of my encounter with Comprehensible Input. I was teaching by day and going back to University by night to work on a degree in Spanish. Lady Fortune saw to it that I landed in a class of intermediate Spanish taught by a professor from India who had studied all of his Spanish in Spain. He was multilingual and, as I came to understand, spent a great deal of time reflecting on how he would deliver language learning to his students. After my first class with him, he never spoke another word of English to us (which by itself is not necessarily a good teaching plan). At the same time, he ensured that no one in the room was lost for lack of understanding. He spoke to us entirely in Spanish in ways that we always understood. Every session included new vocabulary which he always helped us understand even while we were using them. I would leave those classes, and, on the trip home, discover that I continued to hold internal dialogues in my mind in Spanish. I will never forget the night that this nagging, relentless question arose in my consciousness: why can I not teach Latin this way?

The answer to that question is a long one which I will not belabour here except through summary. I could not teach Latin that way because through all of my own studies and preparations, I was not prepared to speak a word of Latin. I was not prepared to actually read Latin. I had never had the experience of thinking in Latin. I never wrote a single personally communicative sentence in Latin. I was not ever given the chance to try and understand Latin spoken to me for the purpose of communication. I had, through relentless self-imposed determination, mastered the ability to talk at length about the different uses of the ablative case, of compound verbs that require the dative, of verbs of remembering and forgetting that require the genitive, of the difference in primary and secondary sequence. I could tell you what a Ciceronian period was and how utterly overwhelming they could be to try to translate. And yes, translation: it would be a few years before I came to realise that translating Latin or Greek was not at all the same thing as reading those languages which could actually be done, left to right, word for word. Reading these languages as they were written and understanding them as such also creates deeper meaning and understanding in the reader who is then drawn into the text. Translating or decoding classical languages is rather like demanding that the meaning of the text come out and become something foreign to itself - the reader's native language.

About this same time, the American Council on the Teaching of Foreign Languages (ACTFL) published its first edition of the Standards for World Languages. In the course of attempting to afford Latin programs which intend to
survive and thrive in the coming years. 
embrace what ACTFL was offering to us via the four modes of language (listening, reading, speaking and writing), I came across reference to Krashen's work. It would still be another five years before I actually picked up his work and began to try to employ it in my teaching. Meanwhile, I was determined to teach Latin like my Spanish professor was teaching me Spanish. I decided that the problem was that I couldn't speak Latin, so I attempted to focus on that. I created classroom scripts for myself which I painstakingly created using the Latin I knew and what was at the time the first edition of Conversational Latin for Oral Proficiency (Traupman, 1997). The day came when I was ready (with the help of cue cards hidden from student sight all over the room) to speak to my students in Latin of all the classroom management things that we did every day. That's when I encountered what should have been the obvious obstacle: I had prepared myself to speak Latin to them, but I had no idea how to prepare them to understand what I was trying to say. Needless to say, those first attempts were anxiety-provoking in all of us, exhausting and sent me back to ponder. Perhaps Latin was just too different. Perhaps Spanish was just so much easier that it could be taught in a way that immediately communicated. Perhaps I was wasting my time. Those thoughts tortured me because at the same time I found competing thoughts. Latin is a human language. It has an incredibly long history of communicating what all of my own teachers and much of my society claim are important, valuable perhaps even eternal messages for us to understand. If that's so, how can I begin to teach Latin as a language that communicates?

The truth that confronted me each day was that all I was prepared to teach my students was the equivalent of the art of autopsy. That required a dead language and students with the fortitude to cut open the corpse each day. Too many of them were not willing to do that, and they were failing. At this rate, my program would itself die in a few years. That has been true all across our educational landscape. Too many Latin students were not capable of or interested in linguistic autopsy of a dead language. They either went elsewhere for language study, or failed out of our programs before our programs were closed.
In the early 2000's with all of these competing questions stirring in me, a confluence of things moved me on in this quest for Latin as a language that communicates important messages. Despite my first horrible attempts to use Latin in my classroom, I persisted in the idea that I should be able to do that. I also came across the works of James Asher with Total Physical Response (1988), the hypotheses of Stephen Krashen, the natural method used by Hans Oerburg, and the so called 'green bible' of Ray and Seely. By reading their works I was using total physical response to introduce new vocabulary, convincing administrators to purchase Oerburg's Lingua Latina as our textbook (which had no English in it at all), attempting to tell and ask stories and circle words and phrases in my classroom just by trial and error (with no one to ask or model after in Latin). I had read the five hypotheses of Krashen. They made sense on paper, but it would still be several years before they began to be the framework for practices in my classroom. In early 2004, I had the opportunity to attend a one-day lecture with Stephen Krashen in Atlanta followed by a two-day workshop the next year with Jason Fritze in the use of TPRS. In those two live and interactive events, I found much affirmation for what I had been trying, some correctives for what I had misunderstood and the encouragement (at least from modern language colleagues) to persist.

Trying to talk about these things with Latin colleagues was another kind of experience altogether. These were still the days of email listservs. They were a huge advantage to professional collaboration over waiting for annual conferences to arrive for a few days of face to face conversation (often dominated by the reading of papers and no real conversation or collaborative reflection on best practices). The email listserv, however, left awful gaps in the ability to communicate. I boldly brought what I was thinking, doing and trying to the Latin community of teachers there, and it was largely not welcome. I argued the theories as best I could. When asked for examples, I would gladly offer up a recent set of materials and experiences from my classroom. When a mistake was found in my Latin (regardless of whether it was a typo or an actual gap in my knowledge) I was dismissed along with the new theories as someone who simply did not know his Latin. If one did not know the basics of Latin grammar, the usual dismissal went, why should we listen to these theories that are meant for modern languages? Besides, Latin is different, and these things won't work in Latin. I lost count of the times that I was told that nothing I had to offer was worth the conversation because my Latin was bad. I came to understand that accusing another colleague of bad Latin was the quickest and commonest defence against new ideas in our community. Despite this experience of shouting against the traditional winds, two of us decided to create a new listserv. John Piazza (current Latin teacher at Berkley High School) and I formed the Latin Best Practices listserv (now found on Facebook) and quickly established it as a place to discuss 'those second language acquisition practices that help all kinds of students make progress in Latin and which continue to evolve into better practices as they are shared'.

A little over ten years ago in 2008 two colleagues (Rachel Ash and Stephanie Molchen) and I offered what would be the first (and at the time we were sure the last) session at the Institute of the American Classical League introducing Comprehensible Input. To an overflow crowd of about 100 Latin teachers, we offered a reading from Ovid's Metamorphoses - the description of Envy: Met. II.760-782, 790-796. We asked participants to read it to themselves, saying that they had two minutes in which to do so. We then asked them to turn to a partner and describe what they had just read. That discussion did not last long and the level of conversation was very quiet. Over the course of the next hour, the three of us used a variety of CI strategies to deliver what we felt were the unknown vocabulary of this less read text, and we did it completely in Latin. At the end of the hour, we asked participants to read the text again. Within minutes the room was buzzing with conversation and excitement. There were even a few audible gasps. Latin teachers were actually able to read and understand a passage that an hour before many had difficulty with. We had wanted them to experience this approach as much like students as possible, and it seemed they did. What was the first thing that someone said to us afterwards? It consisted of a criticism of some of our pronunciation of a Latin 
word or two (your stress was off in that word). The overwhelming conversation for the next two days, though, consisted of individuals confessing to us how little of the text they had first been able to read, and how much more they understood after the CI framed activities.

Ten years later, Comprehensible Input is a reality that everyone is contending with. Scores of Latin teachers have fully embraced it. Many more are taking their first steps with it. Thousands are participating in conversations on the internet about it, collaborating and sharing ideas as well as being willing to ask questions about it. Even those who reject it now know that they must include it in their conversations, planning and structures when language pedagogy is part of the conversation. Sessions offered at the American Classical League's annual Summer Institute now routinely include many which are devoted to CI-related topics, and this is true at regional and state level classics professional meetings as well. Conferences that used to be dismissed by Latin teachers as for modern languages only now enjoy a healthy contingent of Latin teachers who are present for and offering workshops on their use of second language acquisition principles which stem from or are in dialogue with Comprehensible Input. Younger teachers who are joining the field either have come from programs that have included CI in their array of second language acquisition studies, or they have heard from their in-field colleagues that $\mathrm{CI}$ is something they must know about. That has created a new reality in which novice as well as veteran classical language teachers have in common a new willingness to learn how to teach Latin and Greek differently from how they themselves learned.

Before I turn to the principles of CI, I want to bring my own story up to the present. 14 years ago, I took the position that I now hold in a large (3000+ students) metropolitan high school. The program was staffed by one Latin teacher whom I replaced. There were 130 students in the program offering four years of Latin. Despite the school's multicultural demographics, the Latin program was made up entirely of white and Asian students. By that time, I was fully committed to CI as the framework for how I taught Latin. As I write this in late 2018, our program has grown to 700 students and five full-time Latin teachers. We have a high retention rate from year one to year four (40-60\% depending on the year compared to a more traditional $1-10 \%)$, and a virtual zero failure rate. Our program now matches the school in every demographic including students who are being served by Special

Education for various learning difficulties. Recent enrolment numbers show that our Special Education numbers have almost doubled in the last two years including 121 currently among our total enrolment in Latin. The five of us who teach in the Latin program are clear that we would never go back to anything we have done prior to discovering the principles of Comprehensible Input.

\section{Krashen's Principles of Comprehensible Input}

In what follows, I offer what I now understand to be the principles of Comprehensible Input that can be a complete philosophical framing of pedagogical practices. Those are important distinctions. The principles provide an intellectual framework for the various (dozens) of practices which we are creating, using, sharing and evolving in our classrooms. What I am calling the principles of CI began as Krashen's five hypotheses. Some time later, he offered a sixth. As I have heard Krashen himself say on numerous occasions, the difference in a hypothesis and a theory is not worth pressing. Both a hypothesis and a theory require evidence that supports their claims, and there is plenty of support to establish the claims of his hypotheses. On the other hand, if you wish to disagree with CI and have what you believe is one instance of non-supporting evidence, there is no amount of evidence that will convince you otherwise. My own experience and that of scores of Latin teachers who have embraced CI is that not only are the principles of CI intellectually appealing and supported by research and studies, but we find that by engaging in pedagogical practices that reflect them, we see significantly positive results in our classrooms. Latin becomes accessible to all kinds of learners, and while failure rates plummet retention rates soar. Below, I will briefly explain each of the principles, i.e. how I explain them in workshops and graduate courses to teachers and teachers in training. I will give reference to Krashen's work and strongly urge those interested in CI to read his own words (all on his website for free access at www.sdkrashen.com). I will then offer an example of what that may look like in a Latin classroom (remember, there are dozens of practices developed and being developed) as well as potential opportunities and obstacles that one may encounter.

\section{The Acquisition-Learning Distinction Principle}

As a Latin teacher, this first principle played more games with my own thinking about our language than perhaps any of the others. Ultimately, I realised that I had spent so many years 'learning' Latin while 'acquiring' very little of it. So, what is this distinction that Krashen draws (1982, pp 10-11)? We must note up front that very often, especially among language teachers, learning language and acquiring language are used almost synonymously, and learning a language is most often spoken of among educators as if it were the same as learning mathematics. This first principle begins a very different framing for us around what we do as teachers of language, even the Latin language. The acquisition of language is unconscious, implicit, picked up from meaningful, interesting messages in the target language. Acquiring language in these ways advances the student's ability in the language. Language learning is a consciously undertaken activity. Learning involves explicit knowledge about the way language works. This kind of knowledge is useful, but only when it comes to editing language that one is already capable of producing. Acquiring language and learning about the nuts and bolts (grammar and syntax) of the language are ultimately both important, but they are not the same and they are not interchangeable. Acquisition moves the student from novice to intermediate to advanced and above in the various proficiencies of listening, reading, speaking and writing a language, but explicit learning of the grammar of a language is only useful after the student can produce the language. Traditional forms of teaching second languages, in 
particularly our own classical languages of Latin and Ancient Greek, have focused on learning with very little, perhaps even accidental occasions of acquisition.

Traditional Latin classrooms and all textbooks that I know of follow a grammar syllabus thereby establishing the learning approach over acquisition. We begin chapter 1 in a textbook with a look at first declension nouns or first conjugation verbs or both because, well, they are first in the syllabus. This presumes that all students know what a noun and a verb are, what declension and conjugation mean, and various other parts of speech. We relentlessly decry how many students 'do not know their grammar in English' so how are we expected to teach it to them in Latin. The simple fact is that they already speak, read, write and understand English without knowing their grammar. How might an acquisition approach look on day one? The Latin teacher has written these words with their English equivalents on the board: sella, surge, $i$, ad, conside. The teacher pronounces each Latin word and what it means in English. The teacher points to the class, and then to surge. The teacher says: discipuli, surgite (and gestures for them to rise). They do, of course. Then, the teacher says: discipuli, considite (and gestures for them to sit - which they do). The teacher then calls on one after another student, points to the appropriate words and slowly tells the student: surge. $i$ ad sellam. conside. surge. i ad sellam tuam. conside.

Latin teachers will notice that I have not called for explaining the imperative, or the differences in singular and plural commands, or that I have used the accusative case as object of the preposition while only listing it on the board in the nominative. I have used none of those words with students. What this example models is communicating to students with understandable messages in Latin. In short order of time (within the same class period) the teacher can add other nouns and verbs in whatever declension and conjugations desired so that by the end of the period students - all students - will have an initial acquisition of many new words that means something to them in Latin, words like: sella, surge, $i$, ad, conside, sume, fer, animal, canis, feles, ursa, da, sacculus, quis, vult, habere, graphidum, calamus, charta, liber, et al.

Offered as understandable messages in Latin, these words will not be forgotten.
They are not memorised. They are not learned. They are acquired. We find in our own practices that beginning a new semester or school year with extensive reviews is simply not necessary. Students will not forget what they have acquired.

The opportunities afforded by focus on acquisition are many. The example above demonstrates several. We can focus on the immediate environment, as we and students create it, and make that environment and what we do in it the immediate context for learning. Why should students have to wait until the chapter on second declension to talk about books, friends, pencils and pens, or until the chapter on the third declension to talk about mother, father, brothers and sisters? With an acquisition focus, who students are and where they gather for study can become one with the language they are learning. Acquisition like this focuses first on listening. I found early and repeated surprising results from this. Students' accuracy in pronunciation and spelling of Latin increased rapidly - far more rapidly than when I explicitly taught them the rules for pronunciation and despite repeated remarks about the phonetic quality of Latin (no silent letters, no ambiguous sounds, etc.). Teaching for acquisition moves the experience of learning from facing into a page to a face-to-face experience-which is the most basic form of human communication.

There will be potential obstacles for a Latin teacher who shifts from a learning to an acquisition focus. It presumes on the front end that Latin teachers are prepared to speak Latin in a meaningful way with students. For many, this is not true even in the most rudimentary level. I once had a conversation with a veteran Latin teacher who, upon hearing me present on CI-based Latin instruction, said that while he could teach students about the imperative mood with ease, he had no idea what to do with them communicatively. Latin teachers will need support to fill in their own lack of the acquisition of the language (that's another article). Many will immediately ask: when will they learn their grammar? While that is also another article (which is addressed in this series) I can offer one comment. As students acquire the language, they will ask questions about things they notice. These noticed things will be the grammar that we would otherwise be teaching them though not with the symmetry or ease of explicit teaching. When they want to know why we said sellam instead of sella, we can within seconds explain that when the word is the object of an action or movement, we add an $m$ to make that clear. Latin works like that. Period. That will satisfy. It will be the kind of explanation that they are both ready for and for which they really need no prior knowledge. Down the road, after they are capable of producing the language to some degree, we may offer them periods of explicit grammar instruction - simply for them to use while editing their own work. After all, that's what grammars are for.

\section{The Natural Order Principle}

The principle of the Natural Order (Krashen, 1982, pp. 12-14) functions like an operating system on a computer always there and running in the background, perhaps gathering data for later use, but never quite obvious to the user. As a hypothesis it states that there is an order in which people acquire a language. The order is different for different languages, but we don't know what that order is for most languages. Even if we did know, creating a syllabus based on the natural order would be ineffective because then we would be tempted to teach for learning rather than acquisition. The important thing for the teacher to understand from this principle (and keep running in the background of what we do) is that a student will not acquire a feature of the language until he/she is ready. In the meantime, the teacher's focus must be on giving students more understandable input. Because research has not been done on most languages to determine the natural order of acquisition, we as teachers are simply invited to observe. My own observation over the years is that students in Latin seem to be slower to acquire noun endings than they do verb endings. Despite the fact that I as a student was forced to memorise noun endings immediately and up front, they seem to be very slowly acquired for output in Latin. The good news is that despite that slow uptake, noun endings do not seem to hinder listening and reading comprehension. Since our job is to continuously give them understandable input (listening and reading) they will be 
continuously exposed to all of those noun endings. It should be no surprise, then, that the ones they seem to acquire first are nominatives and accusatives - since they appear much more frequently in texts.

The opportunities for classroom practices framed by this principle are simple and already stated above. On a daily basis, the teacher must ask: what understandable input will I speak and/or place in front of my students to read? If our input is understandable in Latin (without the need for tedious translation) students will make progress, and the natural order of the language will unfold in their experience. The obstacle to embracing this principle is also simple and really already addressed: can we who were trained with a grammar syllabus trust that there is a natural order to how Latin is acquired and that the focus on acquisition really works? We might do well, when given the opportunity, to inquire of friends and colleagues whose first languages are highly inflected (Russian, Slavic, Polish, Greek, et al) about their memories of getting all those noun endings right. At first, they may dismiss the question because, of course, they acquired these things first and only learned them grammatically later. What do they remember their parents doing and saying when they were very small that they recall later being about getting those endings right? This may console us that languages as inflected as Latin can be acquired and that there is an order to it which we can trust.

\section{The Monitor Principle}

The Monitor Principle indicates how the CI approach to teaching languages is well rooted in cognitive psychology as it turns our attention to the internal selfconsciousness that we all have about the use of language. Krashen calls this internal self-consciousness the monitor (1982, pp.15-19). Self-consciousness is a tricky aspect of human personality perhaps best described as a sort of blessing-curse. In any endeavour, the right amount of self-consciousness can help us improve skill sets, notice our ways of relating to others around us, protect ourselves and take advantage of good opportunities. At the same time, too much self-consciousness begins to interfere with all of those things. Skills that truly do belong to us suffer with rising self-consciousness (ask any athlete or musician how that works).

Relationships become awkward, and dangers and opportunities can be misread with too much self-consciousness.

Self-consciousness in great amounts can become entirely paralysing. So, too, when the self-consciousness is about the language we are using or trying to use especially when that language is new to us.

In the Latin classroom, working with the Monitor Principle as framework to our teaching means a greater use of scaffolding activities so that individual students feel supported and rarely if ever isolated or made the centre of attention (which is different if they volunteer to be the centre of attention). Once again, we see the first principle - acquisition - as the driver of how this principle works. If we are routinely delivering understandable messages in Latin (by speaking and offering readings) the students' internal self-consciousness will keep a low profile. When it is invoked, it will work with some confidence. In addition to scaffolding, teachers can learn to be the sympathetic listener and reader of student-produced Latin. When the student says: Fredericus est amicum et nos placet ire ad ludus, the teacher understands and says back: Ah, Fredericus est amicus? vobis placet ire ad ludum? By being the sympathetic listener and reader of student output, teachers keep the self-consciousness of the monitor in low profile while at the same time offering repetitions of good Latin.

The opportunities and obstacles of working with the Monitor Principle are the same. As teachers who know the explicit grammar of the language extremely well, we are inclined to correct student mistakes, both in the moment and on paper. The hours that teachers spend writing corrections on student papers is beyond the imagination of most people except for the teachers who do it, and those hours are wasted. Repeated research (Truscott, 2007) indicates that the written correction of students' writing in second language has the opposite effect to the teacher's intent. Rather than make progress in the language, the error corrections cause students to retreat in their writing ability to less advanced stages in an attempt to avoid errors. This is the self-consciousness of the monitor working as an obstacle. A teacher who acts as sympathetic listener and reader, who models back good Latin will help cultivate a healthy monitor in students. Then, when students are capable of producing the language (likely in intermediate levels of work) they may offer short periods of explicit grammar instruction for the use of editing their own work.

\section{The Input Principle}

At first glance, our modern language colleagues struggle with this principle more than we classical language teachers. They want their students to begin speaking their languages immediately, and they have traditionally done this by forcing output through scripted dialogues and 'total immersion' classrooms where the teacher refuses to speak any of L1 thereby forcing students into L2. These methods simply don't work and frighten many students away (or fail them away) thinking that they don't have second language capacity. CI principles recognise that speaking languages is hardwired into the human brain. There is no question that each student has the capacity for acquiring a second language. The question is how to facilitate that acquisition.

Latin and ancient Greek teachers struggle with this principle, too. While we have traditionally not even expected our students to speak our languages, we have expected them to interact with the grammar and syntax of the language from day one so that they could begin translating them into their native languages. Under the cover of translation, we, too, have rushed to some sort of output. The motivation is likely the same. We want output from our students in some form as evidence that they are learning.

The Input Principle (Krashen, 1982, pp. 20-29) maintains that acquisition happens when learners receive understandable messages in the target language, that is, understandable input. There are two forms of language input: listening and reading. The research behind this principle indicates that both forms of input are necessary for acquisition, but ultimately reading is slightly more effective. We know that human beings are capable of acquiring human language even with impediments to sight and sound, but even so, sight and sound are the regular vehicles through which human beings acquire language. Ultimately, this 
principle of Input holds that if we want students to engage in L2 output (speaking and writing) it will be as a direct result of the understandable input they receiveand that must be huge amounts of input. Every day with the Latin teacher, then, Latin students will need to hear from their teacher a lot of Latin that they can understand. They will require Latin to read that they can understand without having to translate it into English (translation and reading are not the same thing and constitute separate skills).

This is where the obstacles arise for the Latin teacher. Immediately, from our traditional training, we wonder aloud why bother with all this speaking Latin when we do not ever expect our students to speak or write in Latin. We want them to read Latin so that they can access the great texts of the literary tradition. It is precisely there that opportunity meets obstacle. If we wish students to acquire Latin so that they can actually read it, they will need loads of understandable input through sound and sight. We have omitted these processes in the past and moved ahead to grammar rules and translation. We have asked students to translate into English things that they cannot read. It becomes a kind of linguistic algebra, solving for $\mathrm{X}$ with an outcome that almost always becomes: translation into English words things that make no sense to the student at all - and that is for those who persist. We simply either exclude many others from the beginning, or they fail out of our programs. We must focus on the promise here. When we offer our students routinely and consistently Latin that they can understand through listening and reading, they will - all kinds of learners acquire a growing ability to understand Latin texts. If reading and understanding the literature of the Latin tradition is our goal, we must deliver understandable input to our students through listening and reading. That raises other challenges that will also be the focus of articles in this series: building backwards from texts that are too difficult for our students and offering them in understandable bites appropriate for their proficiency level.

\section{The Affective Filter Principle}

While this principle comes towards the end of the list of CI principles, I have come to see it as the sine qua non of this framework, meaning this. Even if we had all of the other principles in place and adhered to perfectly, the absence of attention to the affective filter at work in all of our students would constitute a missing bridge between the island of student learning and the teacher's mainland. The human affective filter is made up of various human emotional qualities including spectra within the human of motivation and lethargy, self-esteem and self-doubt, confidence and anxiety, calm and stress. As we can easily imagine, the affective filter is deeply shaped by an individual's upbringing as well as inherent traits. In other words, nurture and nature are at play in what constitutes the affective filter. The Affective Filter Principle (Krashen, 1982 pp. 30-31) acknowledges that each student walks into our classrooms with this whole array of feeling-state possibilities. There will always be circumstances at work outside or our purview which have set those feelings into motion before they ever see us. We are not responsible for that. The Affective Filter Principle, however, acknowledges that those feelings and emotional patterns help and hinder language acquisition. Succinctly put, it observes that when the affective filter rises (i.e. levels of anxiety rise), acquisition of the second language diminishes. Whether the L2 teacher wishes to deal with student feelings and emotions or not, the reality is that whatever is going on with their emotional states has a direct effect on the language we are trying to help them acquire in L2. This is where the Affective Filter Principle ties back into the first - Acquisition vs Learning Principle and the Input Principle. We know that input activities and communicative tasks that focus on acquisition tend to lower stress; those other things that we might do which focus on learning (explicit instruction) tend to increase stress and anxiety.

With this most essential principle of CI, I am afraid that the opportunities and obstacles will be at immediate odds within the teacher. The opportunities should become obvious: when we plan our lessons, they should focus on lots of understandable input, stories and communicative tasks in which students forget that we are working in Latin and become lost in the 'flow' of the language even in its simplest forms. When students remark how quickly the class time passed, we know that this has happened. At the same time, however, creating and facilitating these kinds of lessons can become for the teacher - especially one new to CI - rather exhausting. The exhausted teacher (of any languages) will resort to what is known and familiar to him/her. In other words, the teacher has an affective filter, too. As stress rises for the teacher who is producing understandable input for the student, the teacher will be more inclined to give a grammar lecture, a culture discussion, reading or worksheet in English, or give students grammar and translation assignments that they can do 'quietly at their desks' so that the teacher can recover. These are the realities. Those of us using CI in the field now for more than a few years know that, over time, Latin teachers become more capable of offering acquisition-accessible lessons for their students with less tendency to exhaust themselves. Other writers in this series will demonstrate and discuss the rhythms and flow of CI-based lessons that help the teacher navigate the ground between what nurtures the students' affective filters without spoiling their own.

\section{The Compelling Input Principle}

In an essay subsequent to his book, Krashen acknowledges a sixth hypothesis which he calls the compelling input hypothesis (2013). Simply put, he proposes based on evidence that acquisition of L2 is more successful when the input (reading and listening) is made up of material that the learner finds compelling. We can see the immediate connection to the Affective Filter Principle. This Compelling Principle implies the importance of learner's choice, and choice may be one way of lowering the affective filter and inviting students into the understandable input that we have planned for them - if our planning has taken into consideration student choices about material content. There is also, then, an implicit requirement that compelling material only works if it is also comprehensible. When teachers are willing to bring understandable messages to their students that are also compelling to their students, they are already acknowledging the 
communicative nature of teaching and learning especially in an L2 classroom. To offer input that is both understandable and compelling, we must know something about our students in each particular class every term that we teach. Who they are, what drives them, their creative abilities, fears, dreams and aspirations - all aspects of the make-up of the affective filter - tell us something of who they are and what kinds of material they will lean into both emotionally and physically when I put it before them. In a recent class of fourth year Latin students, a class that happened to be all girls in their last year of high school, I placed a list of 1000 fables from the Latin literary tradition divided by categories before them and asked them identify their favorite categories. They chose the categories of bears, wolves, goddesses and women. We did not have time to read 1000 fables, and even if we had, they would not have found them all compelling. The fact that they were the determiners of what we would read added an immediate aspect of the compelling to our work. I am certain that a different class in a different year would have chosen different categories.

Latin teachers traditionally trained will be most inclined to allow some set of external determiners establish their material content. For example, the notion that Caesar must be read in the second year and that Virgil's Aeneid must be conquered by the end of the curriculum are old notions that are rarely challenged. To put the challenge to that notion before us quickly: if one intends on teaching only male students with a proclivity for war who have been pre-selected by their high-achieving and well-demonstrated willingness to persevere under all constraints and only those kinds of students, then proceed to Caesar and Virgil. The Latin program will remain small, elite and inaccessible to most students - that is if it continues to be supported by schools and systems who find small elite programs impractical. The fact is that both Caesar and Virgil write at a level that is well beyond what students in high school and even university programs are capable of reading and understanding. Caesar and Virgil as required texts, if we are honest, reflect a time when only white, affluent, overtly scholarly male students were the intended audience. They became the norm for what teaching and learning Latin meant, and those programs are either gone from our academic landscape or they are in the final hours of death.

The Compelling Principle offers real opportunity, however. The literary tradition of the Latin language is much larger than the tiny period of the classical golden age, and its content far broader than war and epic. Latin writers treat religion and love, philosophy and history, fables and magic, war and art, epic and lyric, comedy and tragedy, prose and verse, scientific speculation and mathematical inquiry. Most of that literature is far too advanced for the students in our classrooms (and if we are honest, for us as well). However, we who teach Latin do have the capacity to take on any of these areas, explore and adapt them for our students at a level that they are able to understand. Several years ago, I took one line from Quintilian's Institutiones (I.3.12) about children learning their mores inter ludendum. I offered vocabulary to my students that would be required for discussions about the games (both table and athletic) they liked to play, how they were played, and why they liked to play them. We discussed, in Latin, various qualitates as mores that might be gained or confronted in playing games-like virtus, auctoritas, severitas, gravitas, comitas, veritas, honestas et al (mostly taken from Cicero). In Latin we defined these terms and talked about how they might be encountered in particular games. I taught them to play the Roman ball game Trigon, and again, we discussed which mores/qualities might be at play in that game for players and spectators. They wrote about this game, their experience, and how it compared and contrasted with their favourite American games - in Latin. We did the same with Tali, gambling and playing games at Saturnalia. Not a single student complained about all the time we spent on games, game-playing and discussions about moral qualities and how they reveal themselves in gameplaying. They did not read large portions of Quintilian, Cicero or Macrobius, but the works of each of these found their way into our experiences of acquiring Latin because students found this content that I created out of the classical literature compelling.

\section{Conclusion}

I close with some final commentary on the opportunities and obstacles that the principles of $\mathrm{CI}$ bring if they are engaged as the pedagogical framework in a Latin or Ancient Greek program. A university professor once remarked to me that if they were to embrace this approach, they would have to change everything. With that, she dismissed any more conversation about Comprehensible Input. In some respects, she is right. Teachers and professors who have their set authors, their traditional texts, and an established way of conducting classes would feel like they were indeed changing everything if they were to embrace CI principles for their program. Underneath those fixed externals which often are also attached to research and writing projects for the university professor is the unspoken reality: most of us were never allowed opportunities to acquire these languages as modes of communication. I speculate that the majority of Latinists have never spoken Latin or if they did it was in a short and fun sort of temporary experience, certainly nothing they or others expected them to do in a classroom. The vast majority do not routinely write in Latin even though they likely are masters of the Latin grammar and may even teach advanced courses in Latin grammar and syntax. As the earlier mentioned teacher articulated, there is no significant connection between grammar study and writing ability in a language (Krashen, 1988). The necessity of becoming acquainted with this term's students, creating spoken and reading materials for them that they find compelling does upend the cart of what teachers and professors call their curriculum, and yet the very word curriculum implores movement, swift movement and change, does it not?

The opportunities that CI principles afford are nothing short of reintroducing humanity and the realities of human experience back into the classical languages that are the core of the humanities. Rather than force this term's students through the traditional corpus of Latin and Greek content, teachers and professors framing their programs with CI principles actually begin to set up communication, dialogue, between the ancient corpus of literature and the living, breathing students before them. Teachers of the classics have the opportunity of knowing not only a Virgil, Cicero or Aesop, a Camilla, Lucretia or Lesbia. They have the opportunity of becoming acquainted with Rodney, Rahul and Malik, 
Rachondra, Monica and Haley. More to the point, they have the opportunity to help these living breathing students in front of them begin to listen to and speak back to our classical progenitors in their own, modern Latin words and thoughts. If we rise to those opportunities in the face of the obstacles we encounter, those students will not forget their Latin. That is the last observation I will make. Language that is acquired is not forgotten. Language that is learned, is.

Robert Patrick, PhD, Teacher at
Parkview High School, Assistant
Professor in the Language and
Literacy Education Department of
the University of Georgia
robert.patrick59@gmail.com

\section{References}

Asher, J. (1988). Learning Another Language Through Actions. Los Gatos, CA, Sky Oaks Productions.

Krashen, S. (1982). Principles and Practices of Second Language Acquisition. Los Angeles, Pergamon.

Krashen, S. (1988). Teaching Grammar: Why Bother? Online essay previously published in California English (3) 3.8. Available online: http://www.sdkrashen.com/content/articles/ teaching_grammar_why_bother.pdf

Krashen, S. (2013). The Compelling (and not just interesting) Hypothesis. Available online: http://www.sdkrashen.com/content/articles/ the_compelling_input_hypothesis.pdf

Orberg, H. (2003). Lingua Latina Per Se Illustrata. Skovvangen, Denmark, Domus Latina.

Ray and Seely. (1997). Fluency Through TPR Storytelling. Berkley, CA, Command Performance Language Institute.

Traupman, J. (1997). Conversational Latin for Oral Proficiency. Waucaunda, IL, BolchazyCarducci.

Truscott, J. (2007). The Effect of Error Correction on Learners Ability to Write Accurately. Journal of Second Language Writing. 